\title{
Pengaruh work-life balance, Lingkungan Kerja dan Kompensasi terhadap Kinerja karyawan PT Gunanusa Eramandiri
}

\author{
Inna Nisawati Mardiani \\ Universitas Pelita Bangsa \\ inna@pelitabangsa.ac.id \\ Alfin Widiyanto \\ Universitas Pelita Bangsa \\ alfinwidiyanto885@gmail.com
}

\begin{abstract}
This study aims to determine the effect of work-life balance, job satisfaction and compensation on employee performance at PT Gunanusa Eramandiri. The population in this study were all employees of the production section, amounting to 57 employees, using saturated sample techniques. By using data collection methods through questionnaires and secondary data, namely data obtained from companies, data obtained from research is analyzed with quantitative analysis methods, namely multiple regression equations. The results showed that work-life balance has an effect on employee performance. Work environment has an effect on employee performance. Compensation affects employee performance. Furthermore, companies need to increase the share of time, improve environmental conditions and increase benefits, all of which are done to improve employee performance.
\end{abstract}

Keywords work-life balance, work environment, compensation and employee performance

\section{LATAR BELAKANG}

Perusahaan perlu membuat kebijakan yang tepat dengan tujuan agar dapat bertahan, bersaing dengan perusahaan lain, dan perusahaan pun mampu meningkatkan elektabilitasnya untuk semakin mendapat kepercayaan oleh konsumen atau masyarakat. Sumber Daya Manusia memiliki peranan yang sangat penting sebagai faktor penentu keberhasilan organisasi dalam mencapai kesuksesan. Kesadaran akan paradigma tersebut telah membawa banyak organisasi merumuskan hal-hal apa yang menjadi konsentrasi Departemen SDM untuk menciptakan karyawan yang berkompetensi bahkan mampu meningkatkan kinerja Karyawan

Keberadaan sumber daya manusia di dalam suatu perusahaan memegang peranan sangat penting. Tenaga kerja memiliki potensi yang besar untuk menjalankan aktivitas perusahaan. Potensi setiap sumber daya manusia yang ada dalam perusahaan harus dapat dimanfaatkan dengan sebaik-baiknya sehingga mampu menerapkan output optimal

Setiap perusahaan memiliki strategi bersaing untuk dapat bertahan di era globalisasaat ini. Dimana globalisasi mendorong suatu perusahaan untuk menjadi lebih efektif dan efisien guna mengikuti perubahan-perubahan yang muncul begitu pesat. Strategi yang diterapkan dapat dengan mengembangkan dan meningkatkan kinerja karyawan. Peningkatan kinerja karyawan dapat dilakukan dengan work-life balance yang baik,lingkungan kerja yang baik dan pemberian kompensasi 
PT. Gunanusa Eramandiri merupakan perusahaan yang bergerak di bidang industri makanan seperti kacang almond, peanut, dan hezelnut. Sumber daya manusia merupakan salah satu yang mendukung kelancaran kegiatan produksi di PT Gunanusa Eramandiri,oleh karena itu perlu upaya untuk peningkatan kinerja karyawan. Semakin meningkatnya target dan rumitnya produk yang dipesan oleh customer diperlukan kinerja yang tinggi serta tenaga kerja yang handal dalam menjalankan pekerjaan. Masih rendahnya kinerja karyawan dilihat dari rendahnya kualitas kerja, tingkat pengetahuan karyawan yang mayoritas rendah sehingga terkadang karyawan masih kesulitan dalam mengerjakan suatu produk, maka diperlukan peningkatan kinerja karyawan. Penelitian sebelumnya menunjukkan bahwa ada hubungan yang signifikan antara work-life balance dengan kinerja karyawan (Dina, 2018; Saina et al., 2016; Sarikit, 2017).

Work life balance merupakan keseimbangan antara kehidupan pribadi dan kehidupan kerja. Dalam pandangan karyawan work life balance merupakan pilihan mengelola kewajiban kerja dan pribadi atau tanggung jawab terhadap keluarga, sedangkan dalam pandangan perusahaan work life balance merupakan tantangan untuk menciptakan budaya yang mendukung diperusahaan dimana karyawan dapat fokus pada pekerjaan mereka sementara di tempat kerja (Asepta \& Maruno, 2017). Work life balance merupakan konsep keseimbangan yang melibatkan ambisi atau karir dengan kebahagiaan, waktu luang, keluarga dan pengembangan spiritual. Keseimbangan antara kehidupan didalam pekerjaan yang baik akan mengahasilkan semangat kerja yang tinggi, timbulnya perasaan puas terhadap pekerjaan yang dimiliki, dan adanya rasa tanggung jawab penuh baik didalam pekerjaan maupun didalam kehidupan pribadi.

Demi mendukung meningkatnnya kinerja dan kepuasan kerja dibutuhkan lingkungan kerja yang nyaman, efektif dan efesien. Lingkungan kerja merupakan salah satu faktor yang dapat mempengaruhi kepuasan kerja karyawan untuk mencapai tujuan perusahaan (Sitinjak, 2018). Lingkungan kerja merupakan segala sesuatu yang ada disekitar para pekerja, yang dapat mempengaruhi diriya dalam menjalankan tugas-tugas yang dibebankan. Lingkungan kerja ada dua macam yaitu, lingkungan kerja fisik dan lingkungan kerja non fisik. Lingkungan kerja fisik merupakan semua keadaan yang terdapat disekitar tempat kerja, yang mempengaruhi karyawan baik secara langsung maupun tidak langsung. Sedangkan lingkungan kerja non fisik adalah semua keadaan yang terjadi dan yang berkaitan dengan hubungan kerja, baik hubungan dengan atasan maupun hubungan sesama rekan kerja. Terciptanya lingkungan kerja yang nyaman, aman dan menyenangkan merupakan salah satu cara perusahaan untuk dapat meningkatkan kinerja para karyawan. Para karyawan dapat meningkatkan kinerjanya secara maksimal dengan didukung lingkungan kerja yang sesuai.

Kebutuhan materiil yang juga sangat mendasar yakni dilakukan dengan pemberian kompensasi, Salah satu tujuan pemberian konpensasi oleh perusahaan adalah untuk memotivasi karyawan untuk bekerja lebih baik lagi. Kompensasi merupakan sesuatu yang diterima karyawan sebagai pengganti kontribusi jasa mereka pada perusahaan. Setiap karyawan dalam 3 suatu organisasi mempunyai keinginan untuk mendapatkan kompensasi yang sesuai dengan harapan mereka. Apabila harapan tersebut terpenuhi, maka karyawan tersebut akan senantiasa bersemangat dalam bekerja. Handoko (2003) menyatakan bahwa departemen personalia merancang dan mengadministrasikan kompensasi karyawan. Apabila kompensasi yang diberikan sesuai, karyawan lebih terpuaskan dan termotivasi untuk mencapai sasaran organisasi. 


\section{LANDASAN TEORI}

Kinerja

Menurut Edison (2016) kinerja adalah hasil dari suatu proses yang mengacu dan diukur selama produk waktu tertentu berdasarkan ketentuan atau kesepakatan yang telah diterapkan sebelumnya. Menurut Sutrisno (2009)kinerja adalah kesuksesan seseorang dalam melaksanakan tugas,hasil kerja yang dapat dicapai oleh seseorang atau sekelompok orang dalam suatu organisasi sesuai dengan wewenang dan tanggung jawab masing-masing atau tentang bagaimana seseorang diharapkan dapat berfungsi dan berperilaku sesuai dengan tugas yang diberikan. Kinerja dalam bahasa Inggris disebut dengan job performance atau actual performance atau level of performance, yang berarti tingkat keberhasilan pegawai dalam menyelesaikan pekerjaannya. Kinerja bukan merupakan karakteristik individu, seperti bakat atau kemampuan, namun perwujudan dari bakat atau kemampuan itu sendiri. Kinerja adalah hasil kerja yang dicapai pegawai dalam menjalankan tugas dan pekerjaan di suatu organisasi atau perusahaan (Priansa, 2017). Dari pengertian tersebut, maka dapat disimpulkan bahwa kineja merupakan suatu keberhasilan kerja baik dari segi kuantitas dan kualitas dalam melaksanakan tugasnya dalam tanggung jawab bekerja.

\section{Work-life balance}

Work-life balance memiliki konten yang baik dalam pekerjaan dan di luar pekerjaan. Work-life balance adalah suatu keadaan dimana individu mampu mengatur dan membagi antara tanggung jawab pekerjaan,kehidupan pribadi dan kehidupan keluarga dan tanggung jawab lainnya sehingga tidak terjadi konflik anatar kehidupan keluarga dan karir pekerjaan serta adanya peningkatan motivasi ,produktifitas loyalitas terhadap pekerjaan. Work-life balance secara umum berkaitan dengan waktu kerja , fleksibilitas, kesejahteraan, keluarga, demografi, migrasi, waktu luang dan sebagainya.Work-life balance merupakan hal yang esensial karena tidak tercapainya work-life balance berakibat pada rendahnya kepuasan kerja,rendahnya kebahagiaan,work-life conflict,dan burnout pada karyawan. Hafid (2017) berpendapat bahwa work-life balance adalah sebagai kemampuan seseorang atau individuuntuk memenuhi tugas dalam pekerjaannya dan tetap berkomitmen pada keluarga mereka serta tanggung jawab di luar pekerjaan lainnya. Suwatno (2011) berpendapat bahwa jika manajer SDM mengelola program work-life balance dengan baik maka dapat memberikan manfaat dan dampak yang positif. Apabila didefinisikan secara keseluruhan maka Work-life balance adalah sejauh mana individu dapat mengimbangi dan sama-sama merasa puas dalam hal waktu dan keterlibatan psikologis dengan peran mereka di dalam kehidupan kerja dan kehidupan pribadi, misalnya dengan pasangan,orang tua,keluarga,teman dan anggota masyarakat) serta tidak adanya konflik diantara kedua peran tersebut.

\section{Lingkungan Kerja}

Setiap perusahaan yang didirikan ingin memberikan yang terbaik bagi para karyawan dan bagi perusahaan di perusahaannya. Banyak cara untuk mewujudkan semua itu, salah satunya dengan memberikan lingkungan yang nyaman dan aman bagi seluruh karyawannya. Lingkungan kerja merupakan satu hal penting yang perlu diperhatikan oleh perusahaan, karena lingkungan kerja merupakan salah satu kunci sukses bagi suatu perusahaan. Lingkungan kerja adalah keseluruhan sarana dan prasarana kerja yang ada di sekitar karyawan yang sedang melakukan pekerjaannya yang dapat mempengaruhi pelaksanaan pekerjaan. Lingkungan kerja ini meliputi tempat kerja, fasilitas dan alat bantu pekerjaan, kebersihan, pencahayaan, ketenangan, 
termasuk juga hubungan kerja antara orang-orang yang ada di tempat tersebut (Aruan \& Fakhri, 2017)

\section{Kompensasi}

Zainal et al (2013) mengemukakan bahwa kompensasi merupakan suatu yang karyawan dapatkan sebagai pengganti kontribusi jasa mereka pada perusahaan. Kompensasi adalah imbalan yang diperoleh karyawan sebagai balas jasa dari suatu organisasi atau perusahaan. Kompensasi dapat berwujud fisik maupun non fisik.Kompensasi juga dapat mempengaruhi kinerja karyawan,motivasi, serta keinginan untuk tetap memilih pekerjaan itu atau mencari pekerjaan lain. Kompensasi yang sesuai standar industri perusahaan sejenis dan sesuai dengan keinginan maupun latar belakang pendidikan karyawan atau membuat karyawan merasa puas akan penghasilannya. Kompensasi adalah semua balas jasa yang diterima seorang karyawan dari perusahaannya sebagai akibat dari jasa/tenaga yang telah diberikan pada perusahaannya tersebut (Kasmuni et al., 2016)

\section{Pengembangan Hipotesis}

\section{Pengaruh Work life balance terhadap kinerja karyawan}

Penelitian yang dilakukan oleh Saina (2016) mengemukakan bahwa work-life balance merupakan keseimbangan kehidupan di dalam pekerjaan. dari masing-masing individu. Keseimbangan dalam bekerja ini merupakan faktor penting yang dapat mendukung meningkatnya kinerja kerja terhadap suatu pekerjaan. Work-life balance adalah sebuah konsep keseimbangan yang melibatkan ambisi atau karir dengan kebahagiaan, waktu luang, keluarga, dan pengembangan spiritual. Program work-life balance yang diterapkan dalam suatu perusahaan diharapkan mampu meningkatkan tingkat kinerja kerja pada karyawan sehingga dapat menimbulkan semangat kerja bagi karyawan dalam menjalankan tugas dan kewajibannya terhadap perusahaan. Berdasarkan penjelasan tersebut dapat dirumuskan hipotesis:

H1: Worklife balance berpengaruh positif terhadap kinerja karyawan.

\section{Pengaruh Lingkungan Kerja terhadap kinerja karyawan}

Menurut Sedarmayanti (2011) lingkungan kerja adalah keseluruhan alat perkakas dan bahan yang dihadapi, lingkungan sekitarnya dimana seseorang bekerja, metode kerjanya serta pengaturan kerjanya baik sebagai perseorangan maupun sebagai kelompok. Penelitian yang meneliti tentang pengaruh lingkungan kerja terhadap kinerja karyawan yang telah dilakukan oleh peneliti terdahulu yaitu Weol (2015)Hasil penelitiannya menunjukkan bahwa lingkungan kerja mempunyai pengaruh yang signifikan dan positif terhadap kinerja karyawan.

$\mathrm{H} 2$ : Lingkungan kerja berpengaruh positif dan signifikan terhadap kinerja karyawan

\section{Pengaruh Kompensasi terhadap kinerja karyawan}

Penelitian yang meneliti tentang pengaruh kompensasi terhadap kinerja karyawan yang telah dilakukan oleh peneliti terdahulu menunjukkan bahwa kompensasi berpengaruh positif terhadap kinerja karyawan (Ekhsan, 2019; Martinus \& Budiyanto, 2016). Kompensasi adalah segala sesuatu yang diterima karyawan sebagai balas jasa untuk kerja mereka. Masalah kompensasi merupakan fungsi yang kompleks atas dasar logis, rasional dan dapat dipertahankan. Hal ini menyangkut banyak faktor emosional dari sudut pandang para karyawan. Bonus dari organisasi mungkin tidak cukup membuat semua karyawan puas dan 
senang dalam bekerja. Seharusnya manajemen mulai memahami keinginan karyawan. Berdasarkan penjelasan tersebut dapat dirumuskan hipotesis:

H3: Kompensasi berpengaruh positif terhadap kinerja karyawan

\section{Design Penelitian}

Berdasarkan kajian teori dan review hasil penelitian terdahulu yang telah dipaparkan, dapat disimpulkan bahwa peningkatan kinerja karyawan secara umum dipengaruhi oleh berbagai faktor. Penelitian ini terfokus pada work life balance, lingkungan kerja, kompensasi dan kinerja. Berdasarkan uraian tersebut, maka dapat dirumuskan desain enelitian sebagaimana tertera pada gambar 1

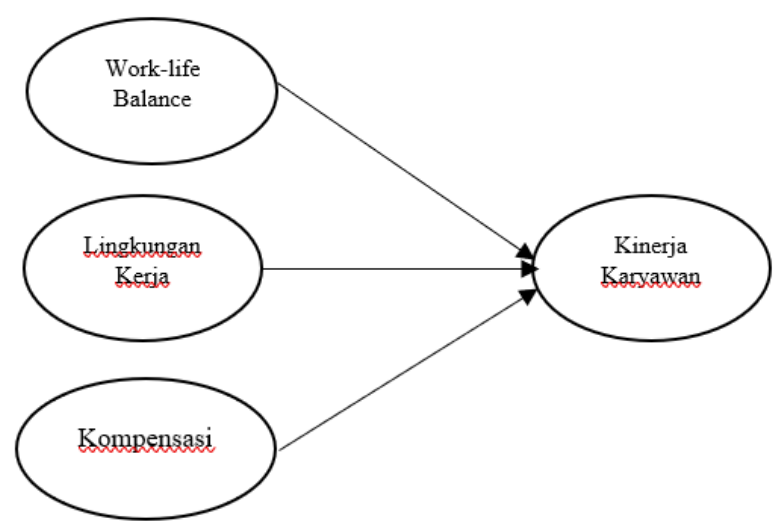

Gambar 1. Design Penelitian

\section{METODE PENELITIAN}

Jenis penelitian ini menggunakan penelitian kuantitatif. Populasi dalam penelitian ini adalah seluruh karyawan PT. Gunanusa Eramandiri bagian produksi yang terdiri dari 57 orang. Penentuan jumlah sampel dalam penelitian ini yaitu metode sampel jenuh dengan cara semua anggota populasi dijadikan sampel. Peneliti mengambil keseluruhan populasi karena peneliti ingin hasil penelitian ini menjadi lebih baik dengan melibatkan seluruh karyawan. Metode pengumpulan data dengan menyebar kuisioner yang berisi pernyataan tertulis kepada karyawan dengan skala ukur yang digunakan yaitu likert. Metode Analis data dengan regresi linier berganda dengan bantuan SPSS.

\section{HASIL DAN PEMBAHASAN}

\section{Analisis Koefisien Determinasi (Adjust R $\mathbf{2}^{\mathbf{2}}$ )}

Koefisien determinasi digunakan untuk mengetahui seberapa besar presentase sumbangan pengaruh variabel independen secara bersama-sama terhadap variabel dependen. Nilai koefisien determinasi dapat dilihat pada tabel 1. 
Tabel 1. Hasil Koefisien Determinasi Model Summary

\begin{tabular}{lrrrr}
\hline Model & R & R Square & $\begin{array}{c}\text { Adjusted R } \\
\text { Square }\end{array}$ & $\begin{array}{l}\text { Std. Error of } \\
\text { the Estimate }\end{array}$ \\
\hline 1 &, $888^{\mathrm{a}}$ &, 789 &, 777 & 1,717 \\
\hline
\end{tabular}

Sumber : Output Program SPSS , 2020

Hasil dari tabel diatas dapat diketahui bahwa koefisien determinasi yang diperoleh yaitu 0,777 atau $(77,7 \%)$. Hal ini berarti bahwa sumbangan pengaruh independen variabel work-life balance,lingkungan kerja dan kompensasi terhadap variabel kinerja karyawan sebesar 77,7 \%. Atau variasi variabel bebas yang digunakan dalam model mampu menjelaskan sebesar 77,7 \% variasi-variasi dependen. Sedangkan sisanya dipengaruhi oleh variabel lain yang tidak dimasukkan dalam model penelitian ini.

\section{Uji F}

Uji F digunakan untuk menguji pengaruh variabel independen secara bersama-sama,uji $F$ pada dasarnya menunjukkan apakah semua variabel bebas yang dimasukkan dalam model mempunyai pengaruh secara bersama sama terhadap variabel terikat,dalam pengambilan keputusan apabila $\mathrm{F}$ hitung lebih besar dari $\mathrm{F}$ tabel dan signifikansi lebih besar dari 0,05 maka dapat dikatakan bahwa ketiga variabel bebas secara bersama-sama mempunyai pengaruh signifikan terhadap variabel terikat

Tabel 2. Hasil Uji F

\begin{tabular}{llrrrrr}
\multicolumn{7}{c}{ ANOVA $^{\text {a }}$} \\
\hline Model & \multicolumn{1}{c}{ Sum of Squares } & Df & Mean Square & F & \multicolumn{1}{c}{ Sig. } \\
\hline 1 & Regression & 582,979 & 3 & 194,326 & 65,901 &, $000^{\mathrm{b}}$ \\
& Residual & 156,284 & 53 & 2,949 & & \\
& Total & 739,263 & 56 & & & \\
\hline
\end{tabular}

Sumber : Output Program SPSS , 2020

Berdasarkan tabel di atas diketahui bahwa nilai F hitung 65,901.Sedangkan nilai F tabel didapat dengan melihat distribusi $\mathrm{F}$ tabel dengan $\mathrm{N}=57$ signifikansi 0,05 serta jumlah variabel independen 3 maka nilai $\mathrm{F}$ tabel sebesar 2,78.Berdasarkan perhitungan di atas nilai $\mathrm{F}$ hitung sebesar 65,901 > dari F tabel sebesar 2,78 serta nilai signifikansi sebesar 0,000 lebih besar dari 0,05 maka dapat disimpulkan bahwa work-life balance,lingkungan kerja dan kompensasi secara bersama sama berpengaruh signifikan terhadap kinerja karyawan

\section{Uji Regresi Linear Berganda}

Adapun regresi linear berganda digunakan dalm penelitian ini dengan tujuan untuk mengetahui ada tidaknya pengaruh variabel bebas terhadap variabel terikat.Perhitungan statistik dalam analisis regresi linear berganda yang digunakan dalam penelitian ini adalah dengan menggunakan bantuan program komputer IBM SPSS 22. Hasil uji analisis regresi linear berganda adalah sebagai berikut : 
Tabel 4. 13 Hasil Uji Regresi Linear Berganda

\begin{tabular}{|c|c|c|c|c|c|c|}
\hline \multicolumn{7}{|c|}{ Coefficients $^{a}$} \\
\hline & & $\begin{array}{r}\text { Unstan } \\
\text { Coeff } \\
\end{array}$ & $\begin{array}{l}\text { ardized } \\
\text { cients }\end{array}$ & $\begin{array}{l}\text { Standardized } \\
\text { Coefficients }\end{array}$ & & \\
\hline \multicolumn{2}{|c|}{ Model } & $\mathrm{B}$ & Std. Error & Beta & $\mathrm{T}$ & Sig. \\
\hline \multirow[t]{4}{*}{1} & (Constant) & 4,611 & 2,582 & & 1,786 &, 080 \\
\hline & $\begin{array}{l}\text { Work-life } \\
\text { balance }\end{array}$ & ,398 & ,094 & ,405 & 4,225 & ,000 \\
\hline & Lingkungan kerja & ,286 & ,104 & 286 & 2,755 & ,008 \\
\hline & Kompensasi & ,276 & ,108 & ,290 & 2,546 & ,014 \\
\hline
\end{tabular}

Sumber : Output Program SPSS , 2020

Hasil analisis regresi linear berganda pada tabel diatas dapat diperoleh koefisien untuk variabel bebas work-life balance $(\mathrm{X} 1)=0,398$ dan Lingkungan kerja $(X 2)=0,286$ dan Kompensasi(X3) $=0,276$ dengan konstanta sebesar 4,611. Sehingga model persamaan regresi linear bergandanya yang diperoleh adalah sebagai berikut :

$\mathrm{Y}=4,611+, 398+, 286+, 276$

Dari persamaan tersebut dapat diambil penjelasan sebagai berikut : Konstanta $=4,611$ Jika variabel work-life balance,lingkungan kerja dan kompensasi diasumsikan tetap,maka kinerja karyawan akan meningkat 4,611. Koefisien work-life balance X1 nilai koefisien work-life balance sebesar 0,398 menyatakan bahwa setiap terjadi kenaikan 1 skor untuk work-life balance akan diikuti terjadinya kenaikan kinerja karyawan sebesar 0,398. Koefisien lingkungan kerja X2 nilai koefisien lingkungan kerja sebesar 0,286 menyatakan bahwa setiap terjadi kenaikan 1 skor untuk lingkungan kerja akan diikuti terjadinya kenaikan kinerja karyawan sebesar 0,286. Koefisien kompensasi X3 nilai koefisien lingkungan kerja sebesar 0,276 menyatakan bahwa setiap terjadi kenaikan 1 skor untuk kompensasi akan diikuti terjadinya kenaikan kinerja karyawan sebesar 0,276

\section{Pembahasan}

\section{Pengaruh work-life balance terhadap kinerja karyawan}

Berdasarkan hasil pengujian hipotesis pertama bahwa work-life balance berpengaruh terhadap kinerja karyawan.Hal ini dibuktikan dengan hasil data dari pengolahan data SPSS 22 yang menyatakan variabel X1 diperoleh t hitung sebesar 4,225 lebih besar dari t tabel 2,005 serta nilai sig sebesar 0,000.Hasil penelitian ini menunjukkan bahwa work-life balance berpengaruh terhadap kinerja karyawan PT Gunanusa Eramandiri.Semakin baik work-life balance yang diberikan perusahaan maka akan semakin baik pula kinerja karyawan PT Gunanusa Eramandiri. Hal ini konsisten dengan penelitian Riani et al (2018) the effect of work-life balance, work strees, and compensation on employee performance menunjukkan bahwa worklife balance berpengaruh signifikan positiv terhadap kinerja karyawan. Priansa (2017) berpendapat bahwa jika manajer SDM mengelola work-life balance dengan baik maka dapat memberikan manfaat dan dampak yang positif seperti meningkatkan kinerja karyawan. 


\section{Pengaruh lingkungan kerja terhadap kinerja karyawan}

Berdasarkan hasil pengujian hipotesis kedua bahwa lingkungan kerja berpengaruh terhadap kinerja karyawan. Hal ini dibuktikan dengan hasil data dari pengolahan data SPSS 22 yang menyatakan variabel X2 diperoleh t hitung sebesar 2,755 lebih besar dari t tabel 2,005 serta nilai sig sebesar 0,008. Hasil penelitian ini menunjukkan bahwa lingkungan kerja berpengaruh terhadap kinerja karyawan PT Gunanusa Eramandiri.Semakin baik lingkungan kerja yang diberikan perusahaan maka akan semakin baik pula kinerja karyawan PT Gunanusa Eramandiri. Hal ini konsisten dengan penelitian Sidanti (2015) menunjukkan bahwa lingkungan kerja berpengaruh signifikan positif terhadap kinerja karyawan

\section{Kompensasi terhadap kinerja karyawan}

Berdasarkan hasil pengujian hipotesis ketiga bahwa kompensasi berpengaruh terhadap kinerja karyawan.Hal ini dibuktikan dengan hasil data dari pengolahan data SPSS 22 yang menyatakan variabel X3 diperoleh thitung sebesar 2,546 lebih besar dari t tabel 2,005 serta nilai sig sebesar 0,014.Hasil penelitian ini menunjukkan bahwa kompensasi berpengaruh terhadap kinerja karyawan PT Gunanusa Eramandiri.Semakin baik kompensasi yang diberikan perusahaan maka akan semakin baik pula kinerja karyawan PT Gunanusa Eramandiri. Hal ini konsisten dengan penelitian. Leonardo (2015) menunjukkan bahwa kompensasi berpengaruh signifikan positif terhadap kinerja karyawan.

\section{KESIMPULAN}

Work-life balance berpengaruh terhadap kinerja karyawan. Artinya bahwa semakin meningkat work-life balance seseorang maka semakin meningkat pula kinerja karyawa. Perusahaan di harapkan untuk selalu memperhatikan dan mengatur bagaimana agar kehidupan karyawan di dalam dan diluar perusahaan bisa seimbang. Lingkungan kerja berpengaruh terhadap kinerja karyawan. Kompensasi berpengaruh terhadap kinerja karyawa. Artinya bahwa semakin nyaman suasana lingkungan kerja maka semakin meningkat pula kinerja karyawan. Perusahaan di harapkan untuk meningkatkan dalam hal suhu udara, area kerja, maupun tata letak ruangan. Selanjutnya perusahaan diharapkan lebih memperhatikan apa yang diinginkan karyawan,masukan-masukan karyawan meengenai perubahan atau tata letak area kerja semakin baik lingkungan kerja akan semakin baik pula kinerja karyawan itu sendiri. Kompensasi berpengaruh terhadap kinerja karyawan, artinya semakin meningkat tingkat kompensasi yang di terima karyawan, maka semakin meningkat pula kinerja karyawan pada perusahaan. Kompensasi dalam hal ini mencakup kompensasi finansial maupun non finansial.

\section{DAFTAR PUSTAKA}

Aruan, Q. S., \& Fakhri, M. (2017). Pengaruh Lingkungan Kerja Terhadap Kepuasan Kerja Karyawan Lapangan Departemen Grasberg.

Asepta, U. Y., \& Maruno, S. H. P. (2017). 1.1. Uki-ARTIKEL: Analisis Pengaruh. JIBEKAJurnal Ilmiah Bisnis Dan Ekonomi Asia, 11(1), 77-85.

Dina, D. (2018). Pengaruh Work-Life Balance Terhadap Kinerja Karyawan di KUD Minatani Brondong Lamongan. Jurnal Indonesia Membangun, 17(2), 1-16.

Edison, E., Anwar, Y., \& Komariyah, I. (2016). Manajemen sumber daya manusia. Bandung: 


\section{Alfabeta.}

Ekhsan, M. (2019). pengaruh kompensasi, pelatihan dan motivasi terhadap kinerja frontliner pada pt bank rakyat indonesia (persero), tbk cabang bekasi. Jurnal Ilmiah Manajemen Bisnis, 5(2), 249.

Hafid, M., \& Prasetio, A. P. (2017). Pengaruh work-life balance terhadap turnover intention (Studi pada karyawan divisi food \& beverage Hotel Indonesia Kempinski Jakarta). SMART-Study \& Management Research, 14(3), 54.

Handoko, T. H. (2003). Manajemen edisi 2. Yogyakarta: BPFE.

Kasmuni, A., Minarsih, M. M., \& Wulan, H. S. (2016). Pengaruh kompensasi, pendidikan dan pelatihan terhadap prestasi kerja karyawan PT. WOODEXINDO Semarang. Journal of Management, 2(2).

Leonardo, E. (2015). Pengaruh pemberian kompensasi terhadap kinerja karyawan pada PT. Kopanitia. Agora, 3(2), 28-31.

Martinus, E., \& Budiyanto, B. (2016). Pengaruh Kompensasi Dan Motivasi Kerja Terhadap Kinerja Karyawan Pada PT. Devina Surabaya. Jurnal Ilmu Dan Riset Manajemen (JIRM), $5(1)$.

Priansa, D. (2017). Perilaku Konsumen dalam Persaingan Bisnis Kontemporer. ALFABETA.

Saina, I., Pio, R., \& Rumawas, W. (2016). Pengaruh Worklife Balance Dan Kompensasi Terhadap Kinerja Karyawan Pada Pt Pln (Persero) Wilayah Suluttenggo Area Manado. Jurnal Administrasi Bisnis UNSRAT, 4(3), 1-9. https://doi.org/10.35797/jab.4.3.2016.12892.

Sarikit, M. (2017). Pengaruh work life balance dan keterikatan pegawai terhadap kinerja pegawai fakultas ilmu sosial dan ilmu politik Universitas Indonesia. Jurnal Manajemen Pendidikan, 8(1), 82-91.

Sidanti, H. (2015). Pengaruh lingkungan kerja, disiplin kerja dan motivasi kerja terhadap kinerja pegawai negeri sipil di sekretariat dprd kabupaten madiun. Jurnal Jibeka, 9(1), 44-53.

Sitinjak, L. N. (2018). Pengaruh Lingkungan Kerja Terhadap Kepuasan Kerja Karyawan (Studi pada Karyawan PT. Mitra Pinasthika Mustika Rent Tangerang Selatan). Jurnal Administrasi Bisnis, 60(2), 162-168.

Sutrisno, E. (2009). Manajemen Sumber Daya Manusia, edisi pertama, cetakan pertama. Penerbit: Kencana Pranada Media Group. Jakarta.

Suwatno, H., \& Priansa, D. J. (2011). Manajemen SDM dalam organisasi Publik dan Bisnis. Bandung: Alfabeta.

Weol, D. H. (2015). Pengaruh lingkungan kerja, pelatihan dan penempatan terhadap kinerja pegawai di Dinas Pendidikan Nasional provinsi Sulawesi Utara. Jurnal Berkala Ilmiah Efisiensi, 15(5).

Zainal, R. (2013). Pengaruh Efektivitas Pengendalian Intern, Asimetri Informasi Dan Kesesuaian Kompensasi Terhadap Kecenderungan Kecurangan Akuntansi (Fraud)(Studi Empiris Kantor Cabang Bank Pemerintah Dan Swasta Di Kota Padang). Jurnal Akuntansi, $1(3)$. 